\title{
Peningkatan Kesejahteraan Masyarakat melalui Partisipasi dan Implementasi Kebijakan dengan Efektivitas Pembangunan Program Dana Desa sebagai Variabel Intervening
}

\author{
Elvina $^{1^{*}}$, Musdhalifah $^{2}$ \\ ${ }^{1,2}$ Sekolah Tinggi Ilmu Ekonomi Labuhanbatu, Sumatera Utara - Indonesia \\ E-mail : elvinahrp19@gmail.com
}

\begin{abstract}
The purpose of this study was to find out how the influence of community participation, implementation, and effectiveness on community welfare, both directly and indirectly. The population in this study were the head of households in Siburbur Village, Subdistrict of Dolok, North Padang Lawas Regency, totaling 132 Household Heads. The sampling technique was carried out using Proportional Random Sampling method, the sample was calculated using the Slovin formula, obtained as many as 101 household heads. Path Analysis used to analyze data, Data processing is assisted with the AMOS program. The results showed that all hypotheses proposed in this study were accepted. This means that there is a positive and significant influence between community participation, implementation of policies and the effectiveness of project on the welfare of the community, both directly and indirectly on the welfare of the community. The path coefficient of community participation has the greatest influence on welfare. This means that community participation is a very important factor in improving community welfare.
\end{abstract}

Key Words: Community Welfare, Participation, Policy Implementation, Effectiveness

\begin{abstract}
Abstrak
Tujuan dari penelitian ini adalah untuk mengetahui bagaimana pengaruh partisipasi masyarakat, implementasi kebijakan dan efektivitas pembangunan terhadap kesejahteraan masyarakat, baik secara langsung maupun tidak langsung. Populasi dalam penelitian ini adalah rumah tangga yang ada di Desa Siburbur Kecamatan Dolok Kabupaten Padang Lawas Utara yang berjumlah 132 Kepala Rumah Tangga. Teknik pengambilan sampel dilakukan dengan metode Proportional Random Sampling, sampel dihitung dengan menggunakan rumus slovin, diperoleh sebanyak 101 kepala rumah tangga. Data dianalisis dengan menggunakan analisis jalur. Pengolahan data dibantu dengan program AMOS. Hasil penelitian menunjukkan bahwa semua hipotesis yang diajukan dalam penelitian ini diterima. Artinya terdapa pengaruh yang positif dan signifikan antara partisipasi masyarakat, implementasi kebijakan dan efektivitas pembangunan terhadap kesejahteraan masyarakat, baik secara langsung maupun tidak langsung terhadap kesejahteraan masyarakat. Koefisien jalur yang paling besar pengaruhnya terhadap kesejahteraan adalah partisipasi masyarkat. Hal ini berarti partisipasi masyarakat merupakan faktor yang sangat penting dalam meningkatkan kesejahteraan masyarakat.
\end{abstract}

Key Words :Kesejahteraan masyarakat, Partisipasi, Implementas Kebijakan, Efektivitas

\section{Latar Belakang}

Kesenjangan pembangunan di perkotaan dan perdesaan dan banyaknya angka kemiskinan di pedesaan telah menjadi perhatian serius pemerintah dan mendorong pemerintah dalam melakukan pemerataan pembangunan. Perhatian pemerintah dalam pemerataan pembangunan cukup besar, hal ini terlihat dari adanya program dana desa yang bertujuan untuk meningkatkan kualitas pembangunan di pedesaan dan pada akhirnya meningkatkan kesejahteraan masyarakat. Aliran dana dari pusat ke daerah juga merupakan sebagai implikasi dari adanya otonomi daerah. 
Dalam kerangka otonomi desa, segala bentuk urusan pemerintahan desa menjadi kewenangan desa, termasuk salah satunya dalam hal pengelolaan keuangan Desa (Prasetyo \& Masdjojo, 2013). Hal ini sesuai dengan pendapat yang dikemukakan oleh Kuncoro (2006) menyatakan bahwa Pembangunan di daerah pedesaan saat ini telah menjadi prioritas sebagai upaya dalam meningkatkan kesejahteraan masyarakat. Kesejahteraan masyarakat di pedesaan sangat memerlukan perhatian pemerintah.Kesejaheraan masayarakat di Desa Siburbur masih belum sesuai dengan yang diharapkan. Hal ini terlihat dari pendapatan perkapita rumah tangga yang masih rendah, tingkat pendidikan masih rendah dan fasilitas kesehatan yang masih kurang memadai. Mayoritas masyarakat di pedesaan bekerja sebagai seorang petani yaitu petani karet dan sawah. Akses transportasi ke desa masih tergolong kurang layak, sehingga menyebabkan nilai jual hasil bertani dari masyarakat tidak sesuai dengan yang diharapkan. Sementara harga kebutuhan pokok yang harus dipenuhi masyarakat untuk konsumsi rumah tangga cukup tinggi, sebagai akibat dari infrastruktur transportasi yang kurang memadai dari perkotaan ke pedesaan. Fahruddin, (2012) menyatakan bahwa kesejahteraan adalah sebuah kondisi dimana seorang dapat memenuhi kebutuhan pokok, baik itu kebutuhan akan makanan, pakaian, tempat tinggal, air minum yang bersih serta kesempatan untuk melanjutkan pendidikan dan memiliki pekerjaan yang memadai yang dapat menunjang kualitas hidupnya sehingga hidupnya bebas dari kemiskinan, kebodohan, ketakutan, atau kekhawatiran sehingga hidupnya aman tentram, baik lahir maupun batin. Tingkat kesejahteraan masyarakat berdasarkan program Badan Koordinasi Keluarga Berencana Nasional (BKKBN) dengan pendataan keluarga dalam rangka program pembangunan dan pengentasan kemiskinan (Dura, 2016). Indikator yang digunakan untuk mengukur kesejahteraan rumah tangga disesuaikan oleh informasi tentang kependudukan, kesehatan dan gizi, pendidikan, ketenagakerjaan, pola konsumsi atau pengeluaran Rumah tangga, perumahan dan lingkungan, dan sosial lainnya (Ekafitri et al., 2014). Menurut Badan Pusat Statistik (2015) indikator yang digunakan untuk mengetahui tingkat kesejahteraan ada delapan, yaitu pendapatan, konsumsi atau pengeluaran keluarga, keadaan tempat tinggal, fasilitas tempat tinggal, kesehatan anggota keluarga, kemudahan mendapatkan pelayanan kesehatan, kemudahan memasukkan anak kejenjang pendidikan, dan kemudahan mendapatkan fasilitas transportasi.

Keberhasilan pembangunan di pedesaan tidak terlepas dari partisipasi masyarakat dalam pembagunan pedesaan. Partisipasi masyarakat sangat diperlukan agar pembangunan di desa dapat dilaksanakan sesuai dengan perencanaan yang sudah ditetapkan. Saputra, (2016) menyatakan bahwa kegagalan berbagai program pembangunan pedesaan di masa lalu disebabkan antara lain karena penyusunan, pelaksanaan dan evaluasi program-program pembangunan pedesaan tidak melibatkan masyarakat. Pembangunan dilakukan dengan tidak aspiratif dan parsitipatif. Proses kebijakan pembangunan lebih mengedepankan paradigma politik sentralistis dan dominannya peranan negara pada arus utama kehidupan bermasyarakat. Menurut Latif, (2014) partisipasi adalah merupakan peran serta warga desa baik dalam merencanakan, melaksanakan, mempertanggungjawabkan maupun dalam menerima hasil-hasil pembangunan. Dalam pengertian ini paling tidak dapat dijumpai adanya tiga hal pokok, yaitu partisipasi merupakan keterlibatan mental emosional; partisipasimenghendaki adanya konstribusi terhadap kepentingan atau tujuan kelompok; dan partisipasi merupakan tanggungjawab terhadap kelompok. Mengenai bentuk-bentuk partisipasi masyarakat, Cohen \& Uphoff (1977) terdiri dari ; 1) partisipasi dalam pembuatan keputusan, 2) partisipasi dalam pelaksanaan, 3) partisipasi dalam penerimaan dan pemanfaatan hasil, dan 4) partisipasi dalam mengevaluasi. Aparatur pemerintah di desa haruslah melakukan pembangunan secara partisipatif dengan melibatkan masyarakat. Pelibatan masyarakat dalam pembangunan dapat berupa penyusunan program , pelaksanaan program, dan juga melibatkan masyarakat dalam melakukan pengawasan agar nantinya program yang telah 
dibuat benar-benar sesuai dengan harapan masyarakat dan dapat meningkatkan kesejahteraan masyarakat.

Disamping itu, untuk meningkatka kesejahteraan masyarakat tidak terlepas dari implementasi kebijakan anggaran dana desa yang telah dirumuskan. Dalam implementasi kebijakan yang ada, pembangunan harus benar-benar dilakukan sesuai dengan yang dirumuskan oleh aparatur desa dengan masayarakat. Prasetyo \& Masdjojo (2013) implementasi kebijakan sesungguhnya tidak hanya menyangkut perilaku badan-badan administratif yang bertanggungjawab untuk melaksanakan program-program dan menimbulkan ketaatan pada kelompok sasaran melainkan menyangkut pula jaringan kekuatan politik, ekonomi, dan sosial yang langsung maupun tidak langsung berpengaruh terhadap perilaku semua pihak yang terlibat dan pada akhirnya terhadap dampak yang diharapkan maupun yang tidak diharapkan.

Menurut Nugroho (2004:158) implementasi kebijakan pada prinsipnya adalah cara agar sebuah kebijakan dapat mencapai tujuannya, tidak lebih dan tidak kurang. Untuk mengimplementasikan kebijakan publik, maka ada dua pilihan langkah yang ada yaitu langsung mengimplementasikan dalam bentuk programprogram atau melalui formulasi kebijakan derivat atau turunan dari kebijakan publik tersebut. Menurut Fahri (2014) masih belum efektifnya program pembangunan disebabkan karena masih adanya Desa yang mengalokasikan penggunaan Dana Desa tidak sejalan dengan prioritas yang diamanatkan pada Peraturan Menteri Desa, Pembangunan Daerah Tertinggal dan Transmigrasi Republik Indonesia dan juga masih belum adanya Peraturan dari pemangku kebijakan yang mengatur prioritas penggunaan Dana Desa. Agustino, 2012:149) menjelaskan bahwa model implementasi kebijakan yang memiliki perspektif top down dikembangkan oleh George C. Edwards III. Dalam pandangan Edwards III, implementasi kebijakan dipengaruhi oleh empat variabel, yaitu: (1) komunikasi; (2) sumberdaya; (3) disposisi; (4) struktur birokrasi. Komunikasi yang baik harus terjalin, birokrasi tidak berbelit dalam pelaksanaan program tepat sasaran dan juga tepat waktu. Partisipasi masyarakat yang baik dan implementasi kebijakan yang baik akan berdampak kepada efektivitas pembangunan. Efektivitas pembangunan berarti pembangunan yang dilaksanakan sesuai dengan kebutuhan masyarakat dengan anggaran yang efisien dan efektif. Pembangunan yang efektif akan tercipta jika masyarakat dilibatkan mulai dari perencanaan sampai pada tahap pelaksanaan program pembangunan. Halim (2002) efektivitas menggambarkan kemampuan pemerintah desa dalam merealisasikan keuangan alokasi dana desa untuk melaksanakan program yang direncanakan dibandingakan dengan target yang telah detetapkan berdasarkan potensi nilai rill . Untuk mengukur efektivitas penggunaan dana desa, ada beberapa aspek penting yang perlu dipertimbangkan yakni (a) pencapaian tujuan, bahwa penggunaan dana desa dapat dikatakan efektif apabila penggunaannyasesuai dengan prioritas kebutuhan sehingga tujuan tercapai; (b) ketepatan waktu, proses penyaluran dan penggunaan dana sesuai dengan waktu pelaksanaan kegiatan yang telah direncanakan hingga berakhirnya kegiatan; (c) sesuai manfaat, dana desa dapat dirasakan manfaatnya oleh masyarakat desa sebagai penerima program; dan (d) hasil sesuai harapan masyarakat (Aziz, 2016).

Berdasarkan uraian di atas, maka rumusan masalah penelitian yaitu apakah partisipasi masyarakat dalam pembangunan desa berpengaruh positif dan signifikan terhadap efektivitas pembangunan?, Apakah implementasi kebijakan berpengaruh positif dan signifikan terhadap efektivitas pembangunan?, Apakah partisipasi masyarakat dalam pembangunan desa berpengaruh positif dan signifikan terhadap peningkatan kesejahteraan masyarakat?, Apakah implementasi kebijakan berpengaruh positif dan signifikan terhadap peningkatan kesejahteraan masyarakat?, dan Apakah efektivitas pembangunan program dana desa berpengaruh positif dan signifikan terhadap kesejahteraan masyarakat? 


\section{Metode Penelitian}

Penelitian ini dilakukan dengan pendekatan metode kuantitatif. Teknik analisis data menggunakan teknik analisis jalur yaitu melihat pengaruh variabel eksogen terhadap variabel endogen baik secara langsung maupun tidak langsung.Populasi dalam penelitian ini adalah rumah tangga di Desa Siburbur yang berjumlah 132 rumah tangga. Setelah dilakukan perhitungan dengan rumus slovin, sampel diperoleh sebanyak 101. Model analisis data dalam penelitian ini adalah analisis jalur (Path Analysis) dengan menggunakan software AMOS 23 , yaitu untuk mengetahui sejauhmana pengaruh variabel penyebab (eksogen) terhadap seperangkat variabel lainnya yang merupakan variabel akibat (endogen) baik ecara langsung maupun tidak langsung melalui variabel perantara (intervening variabel).

\section{Hasil dan Pembahasan}

\subsection{Hasil}

\section{a. Uji Kesesuaian Model}

Sebelum dibahas hasil uji estimasi atau hasil uji hipotesis berkaitan dengan pengaruh pengaruh partisipasi masyarakat, implementasi kebijakan, dan efektivitas pembangunan terhadap kesejahteraan masyarakat baik secara langsung maupun tidak langsung, terlebih dahulu dibahas uji kesesuaian model (goodness of fit tes). Berdasarkan hasil penelitian yang diolah dengan menggunakan AMOS versi 23, uji kesesuaian model dapat dilihat pada Tabel 1 berikut ini:

Tabel 1. Goodness of Fit Test

\begin{tabular}{lccc}
\hline \multicolumn{1}{c}{ Statistik Uji } & Nilai Kritis & Hasil & Keterangan \\
\hline Cmin/DF & $\leq 2,00$ & 1,590 & Fit \\
RMSEA & $\leq 0,08$ & 0,077 & Fit \\
P-value & $\geq 0,05$ & 0,207 & Fit \\
Adjusted Goodness of Fit (AGFI) & $\geq 0,90$ & 0,922 & Fit \\
Gooness of Fit Index (GFI) & $\geq 0,90$ & 0,992 & Fit \\
Comparative Fit Index (CFI) & $\geq 0,90$ & 0,990 & Fit \\
Tucker Lewis Index (TLI) & $\geq 0,90$ & 0,942 & Fit \\
\hline
\end{tabular}

Sumber : Data di olah, 2018

Berdasarkan Tabel 1 di atas menunjukkan bahwa model dalam penelitian adalah baik. Hal ini terlihat dari kriteria pengujian goodness of fit tess sesuai dengan nilai kritis yang telah ditentukan. Nilai chi square 1,590 dimana semakin kecil nilai chi square maka semakin cocok model tersebut. Dan Nilai Root Mean Square Error of Approximation (RMSEA) 0.077 menunjukkan RMSEA close fit karena lebih kecil dari 0,08. Nilai Probability (P-Value) sebesar 0,207 lebih besar dari 0,05 $(\geq 0,05)$, hal ini menandakan data empiris identik dengan teori/model.

Berdasarkan ukuran kecocokan inkremental yaitu membandingkan model yang diusulkan dengan model dasar (baseline model) juga sangat baik karena nilai Tucker-Lewis Index (TLI) sebesar 0,942 termasuk dalam kriteria good fit karena memiliki nilai $\geq 0,90$. Begitu juga dengan nilai Comparative Fit Index (CFI) sebesar 0,990 lebih besar sdari 0,90 ( $\geq$ $0,90)$ termasuk dalam kriteria good fit. Sehingga secara keseluruhan model persamaan analisis jalur yang digunakan dapat diterima dan pengujian hipotesa dapat dilanjutkan. 


\section{b.Uji Hipotesis}

Berdasarkan hasil penelitian yang digambarkan pada path diagram, maka dapat dilihat bentuk hubungan antara variabel partisipasi masyarakat, implementasi kebijakan, dan efektivitas pembangunan terhadap kesejahteraan masyarakat sebagai berikut :

Tabel 2.Uji Hipotesis

\begin{tabular}{|c|c|c|c|c|c|}
\hline & Hubungan & & Estimasi & P-Value & Keputusan \\
\hline $\begin{array}{l}\text { Partisipasi } \\
\text { Masyarakat }\end{array}$ & $--->$ & $\begin{array}{l}\text { Efektivitas } \\
\text { Pembangunan }\end{array}$ & ,375 & 0,000 & Signifikan \\
\hline $\begin{array}{l}\text { Implementasi } \\
\text { Kebijakan }\end{array}$ & $--->$ & $\begin{array}{l}\text { Efektivitas } \\
\text { Pembangunan }\end{array}$ & ,251 & 0,005 & Signifikan \\
\hline $\begin{array}{l}\text { Efektivitas } \\
\text { Pembangunan }\end{array}$ & $--->$ & $\begin{array}{l}\text { Kesejateraan } \\
\text { Masyarakat }\end{array}$ & ,194 & 0,038 & Signifikan \\
\hline $\begin{array}{l}\text { Partisipasi } \\
\text { Masyarakat }\end{array}$ & $--->$ & $\begin{array}{l}\text { Kesejateraan } \\
\text { Masyarakat }\end{array}$ & ,357 & 0,000 & Signifikan \\
\hline $\begin{array}{l}\text { Implementasi } \\
\text { Kebijakan }\end{array}$ & $--->$ & $\begin{array}{l}\text { Kesejateraan } \\
\text { Masyarakat }\end{array}$ & ,256 & 0,003 & Signifikan \\
\hline
\end{tabular}

Sumber : Data di olah, 2018

Hasil uji koefisien regression weights menunjukkanbahwa secara statistik semua hipotesis dapat diterima. Hal ini dapat dilihat dari koefisien jalur antara partisipasi masyarakat terhadap efektivitas pembangunan memiliki p-value sebesar 0,000 $(P=0,000 \leq 0,05)$. Dengan demikian, dapat dapat dijelaskan bahwa partisipasi masyarakat memiliki pengaruh yang positif dan signifikan terhadap efektivitas pembangunan. Artinya semakin tinggi partisipasi yang dilakukan dalam masyarakat dalam pembangunan, akan memiliki pengaruh terhadap terjadinya pembangunan yang semakin efektif.

Koefisien jalur antara implementasi kebijakan terhadap efektivitas pembangunan memiliki koefisien yang positif dengan p-value sebesar $0,005(P=0,005 \leq 0,05)$. Dengan demikian, dapat dapat dijelaskan bahwa implementasi kebijakan memiliki pengaruh yang positif dan signifikan terhadap efektivitas pembangunan. Artinya semakin bagus implementasi kebijakant dalam pembangunan, akan memiliki pengaruh terhadap terjadinya pembangunan yang semakin efektif.

Koefisien jalur antara efektivitas pembangunan terhadap kesejahteraan masyarakat memiliki koefisien yang positif dengan p-value sebesar 0,038 $(P=0,038 \leq 0,05)$. Dengan demikian, dapat dapat dijelaskan bahwa efektivitas pembangunan memiliki pengaruh yang positif dan signifikan terhadap kesejahteraan masyarakat. Artinya apabila efektivitas pembangunan semakin bagus, maka kesejateraan masyarakat juga akan meningkat.

Koefisien jalur partisipasi masyarakat terhadap kesejahteraan masyarakat memiliki koefisien yang positif dengan p-value sebesar $0,000(P=0,000 \leq 0,05)$. Dengan demikian, dapat dapat dijelaskan bahwa partisipasi masyarakat memiliki pengaruh yang positif dan signifikan terhadap kesejahteraan masyarakat. Artinya apabila partisipasi masyarakat semakin bagus, maka kesejateraan masyarakat juga akan meningkat.

Koefisien jalur implementasi kebijakan terhadap kesejahteraan masyarakat memiliki koefisien yang positif dengan p-value sebesar $0,003(P=0,003 \leq 0,05)$. Dengan demikian, dapat dapat dijelaskan bahwa implementasi kebijakan memiliki pengaruh yang positif dan 
signifikan terhadap kesejahteraan masyarakat. Artinya apabila implementasi kebijakan semakin bagus, maka kesejateraan masyarakat juga akan meningkat.

\subsection{Pembahasan}

Berdasarkan hasil penelitian menunjukkan bahwa semua variabel yang diteliti yaitu partisipasi masyarakat, implementasi kebijakan, dan efektivitas pembangunan memiliki pengaruh yang positif dan signifikan terhadap kesejahteraan masyarakat. Dengan adanya partisipasi masyarakat, pengambil kebijakan dalam hal aparatur desa akan mampu membuat perencanaan lebih matang dan tepat demi tercapainya kesejateraan masyarakat. Masyarakat perlu terlibat dalam membuat keputusan, pelaksanaan, partisipasi dalam pemanfaatan secara baik, dan melakukan evaluasi atas pembangunan yang telah dilakukan. Hal ini sesuai dengan pendapat Cohen dan Uphoff (1977) yang menyatakan bahwa bentuk-bentuk partisipasi masyarakat terdiri dari ; 1) partisipasi dalam pembuatan keputusan, 2) partisipasi dalam pelaksanaan, 3) partisipasi dalam penerimaan dan pemanfaatan hasil, dan 4) partisipasi dalam mengevaluasi. Partisipasi masyarkaat juga akan berdampak terhadap efektivitas pembangunan. Artinya jika masyarakat banyak dilibatkan dalam perencanaan pembangunan, maka pembangunan akan dapat dilaksanakan secara efektif. Untuk mengukur efektivitas penggunaan dana desa, ada beberapa aspek penting yang perlu dipertimbangkan yakni (a) pencapaian tujuan, bahwa penggunaan dana desa dapat dikatakan efektif apabila penggunaannyasesuai dengan prioritas kebutuhan sehingga tujuan tercapai; (b) ketepatan waktu, proses penyaluran dan penggunaan dana sesuai dengan waktu pelaksanaan kegiatan yang telah direncanakan hingga berakhirnya kegiatan; (c) sesuai manfaat, dana desa dapat dirasakan manfaatnya oleh masyarakat desa sebagai penerima program; dan (d) hasil sesuai harapan masyarakat (Aziz, 2016).

Berdasarkan perhitungan pengaruh langsung dan tidak langsung diketahui bahwa pengaruh langsung antara partisipasi masyarakat terhadap kesejahteraan masyarakat adalah sebesar 0,1274. Artinya, jika partisipasi masyarakat meningkat sebesar 1 deviasi standar maka kesejahteraan masyarakat akan meningkat sebesar 0,1274 (12,74\%). Sementara itu pengaruh tidak langsung antara partisipasi masyarakat terhadap kesejahteraan masyarakat melalui efektivitas pembangunan sebesar 7,27\%. Hal ini menunjukkan bahwa pengaruh tidak langsung antara partisipasi masyarakat melalui efektivitas pembangunan terhadap kesejahteraan masyarakat memiliki pengaruh yang lebih kecil daripada pengaruh langsung antara partisipasi masyarakat terhadap kesejahteraan masyarakat.

Hasil penelitian juga menunjukkan bahwa implementasi kebijakan berpengaruh positif dan signifikan terhadap kesejahteraan masyarakat. Hal ini mengandung makna bahwa apabila kebijakan diimplementasikan dengan baik, maka akan berdampak juga terhadap kesejahteraan masyarakat. Hasil temuan penelitian tentang adanya pengaruh antara implementasi kebijakan terhadap kesejahteraan masyarakat diperkuat juga dengan penelitian oleh Rusydi, (2012) yang menyatakan bahwa Anggaran Dana Desa (ADD) berpengaruh positif dan signifikan terhadap kesejahteraan masyarakat di Kabupaten Takalar. Hal tersebut dapat dilihat bahwa nilai sig. (probabilitas) sebesar 0,001 jauh lebih kecil dari $\alpha=0.05(0,000<0,05)$ sehingga model penelitian signifikan. Korelasi (keeratan hubungan) antara anggaran dana desa (ADD) dengan kesejahteraan masyarakat (pendapatan perkapita) adalah sebesar 0,994 yang berarti bahwa ADD memiliki hubungan yang sangat kuat terhadap peningkatan kesejahteraan masyarakat. Hasil penelitian oleh Eskamurti (2016) juga menunjukkan bahwa implementasi dinilai memberikan pengaruh yang bermakna terhadap kesejahteraan masyarakat. Hal ini mengindikasikan bahwa semakin baik implementasi kebijakan, maka kesejahteraan akan tercapai, dan begitupun sebaliknya.. Implementasi kebijakan juga akan memberikan pengaruh terhadap efektivitas pembangunan. 
Berdasarkan perhitungan pengaruh langsung dan tidak langsung diketahui bahwa pengaruh langsung antara implementasi kebijakan terhadap kesejahteraan masyarakat adalah sebesar 6,55\%. Hal ini menunjukkan bahwa pengaruh tidak langsung antara implementasi kebijakan melalui efektivitas pembangunan terhadap kesejahteraan masyarakat memiliki pengaruh yang lebih kecil daripada pengaruh langsung antara implementasi kebijakan terhadap kesejahteraan masyarakat. Dengan kata lain, peran dari variabel efekivitas pembangunan sebagai variabel intervening lemah, karena tidak mampu memperkuat hubungan antara implementasi kebijakan terhadap kesejahteraan. Efektivitas pembangunan berpengaruh terhadap kesejahteraan masyarakat. Penelitian tentang Penelitian tentang Dampak Alokasi Dana Desa terhadap Perekonomian telah dilakukan oleh Prasetyanto (2012) hasil kajiannya menunjukkan ADD mampu meningkatkan kinerja fiskal dan perekonomian daerah, mampu mengurangi jumlah penduduk miskin dan meningkatkan produk domestik regional bruto sektor pertanian.

Hasil output analisis jalur dapat dilihat pada gambar berikut ini:

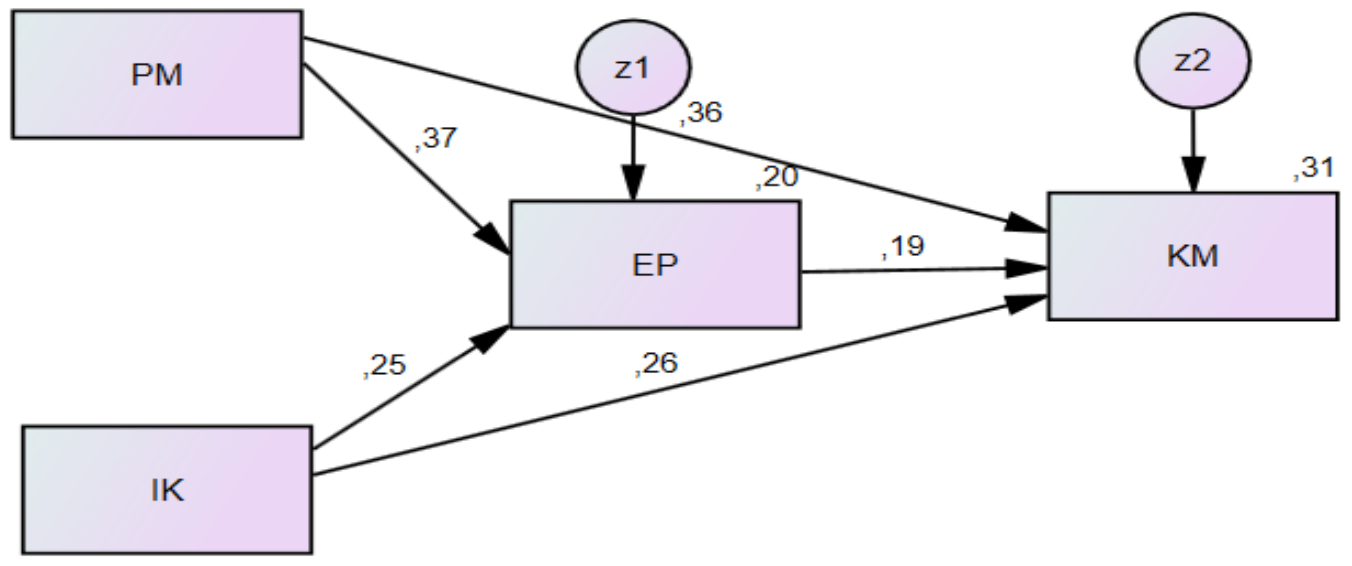

Chi-square= 1,590; $\mathrm{DF}=1 ; \mathrm{CMIN} / \mathrm{DF}=1,590$

;P-Value $=, 207 ;$ RMSEA $=, 077$

;AGFI =,922; GFI =,992; CFI =,990; TLI =,942;

Gambar 1. Output Analisis Jalur

\section{Kesimpulan dan Saran}

\subsection{Kesimpulan}

Berdasarkan hasil penelitian, maka penulis menarik kesimpulan sebagai berikut:

a. Partisipasi masyarakat memiliki pengaruh yang positif dan signifikan terhadap efektivitas pembangunan. Artinya semakin tinggi partisipasi yang dilakukan dalam masyarakat dalam pembangunan, akan memiliki pengaruh terhadap terjadinya pembangunan yang semakin efektif.

b. Implementasi kebijakan memiliki pengaruh yang positif dan signifikan terhadap efektivitas pembangunan. Artinya semakin bagus implementasi kebijakant dalam pembangunan, akan memiliki pengaruh terhadap terjadinya pembangunan yang semakin efektif.

c. Efektivitas pembangunan memiliki pengaruh yang positif dan signifikan terhadap kesejahteraan masyarakat. Artinya apabila efektivitas pembangunan semakin bagus, maka kesejateraan masyarakat juga akan meningkat. 
d. Partisipasi masyarakat memiliki pengaruh yang positif dan signifikan terhadap kesejahteraan masyarakat. Artinya apabila partisipasi masyarakat semakin bagus, maka kesejateraan masyarakat juga akan meningkat.

e. Implementasi kebijakan memiliki pengaruh yang positif dan signifikan terhadap kesejahteraan masyarakat. Artinya apabila implementasi kebijakan semakin bagus, maka kesejateraan masyarakat juga akan meningkat.

f. Model penelitian menunjukkan bahwa variabel penelitian yang terbentuk menunjukkan kriteria baik. Hal ini terlihat dari kriteria pengujian goodness of fit test sesuai dengan nilai kritis yang telah ditentukan.

\subsection{Saran}

Hasil penelitian menunjukkan bahwa partisipasi masyarakat memiliki pengaruh yang paling besar dibandingan dengan pengaruh variabel lainnya terhadap kesejahteraan masyarakat. Oleh karena itu disarankan agar partisipasi mayarakat lebih diperhatikan dalam pembangunan desa. Seperti keterlibatan dalam rapat-rapat dalam merencanakan pembangunan, keterlibatan dalam pelaksanaan pembangunan, dan juga dibilibatkan dalam mengawasai pelaksanaan pembangunan. Disampingan itu juga tidak mengabaikan peran penting implementasi kebijakan yang baik. Implementasi kebijakan yang baik dan melakukan pembangunan yang efektif sesuai dengan perencanaan dan harus sesuai dengan kebutuhan masyarakat. Sehingga nantinya akan berdampak terhadap kesejahteraan masyarakat.

\section{Ucapan Terimakasih}

Peneliti mengucapkan terimakasih sebesar-besarnya kepada Direktur Jenderal Penguatan Riset dan Pengembangan Ristek Dikti yang telah memberikan pendanaan dalam melakukan penelitian ini sesuai dengan surat keputusan nomor 1/E/KPT/2018 tanggal 3 Januari 2018 tentang Penerima Pendanaan Penelitian dan Pengabdian kepada Masyarakat Perguruan Tinggi Negeri Badan Hukum Tahun 2018.

\section{Daftar Pustaka}

Agustino, L. (2012). Dasar-dasar Kebijakan Publik. Bandung: Alfabeta.

Aziz, N. L. L. (2016). The Village Autonomy And The Effectiveness Of Village Fund. Jurnal Penelitian Politik, 13(2), 193-211.

Badan Pusat Statistik. (2015). Indikator Kesejahteraan Rakyat. Jakarta: BPS.

ohen, \& Uphoff. (1977). Rural Development Participation. New York: Cornel Universiy.

Dura, J. (2016). Pengaruh Akuntabilitas Pengelolaan Keuangan Alokasi Dana Desa , Kebijakan

Desa, dan Kelembagaan Desa Terhadap Kesejahteraan Masyarakat, Jurnal JIBEKA . Vol $10,26-32$.

Ekafitri, dkk (2014). Tingkat Kesejahteraan Masyarakat Nelayan Desa Benua Baru Ilir Berdasarkan Indikator Badan Pusat Statistik. JIIA, Volume 2, No. 1, Januari 2014, 2(1).

Eskamurti. (2016). Pengaruh Implementasi Kebijakan Pariwisata terhadap Kesejahteraan Masyarakat. Universitas Sebelas Maret.

Fahri, L. N. (2014). Pengaruh Pelaksanaan Kebijakan Dana Desa terhadap Manajemen Keuangan

Desa dalam Meningkatkan Efektivitas Program Pembangunan Desa, 75-88.

Fahruddin, A. (2012). Pengantar Kesejahteraan Sosial. Bandung: Refika Aditama.

Halim, A. (2002). Akuntansi Keuangan Daerah. Jakarta: Salemba Empat.

Kuncoro. (2006). Ekonomi Pembangunan, Teori, Masalah, dan Kebijakan. Edisi Keempat, Cetakan Pertama. Yogyakarta: STIM YKPN. 
Latif, A. (2014). Peran Partisipasi Masyarakat dalam Peningkatan Pembangunan Desa di Kecamatan Posigadan. Jurnal Madani, 4(1).

Nugroho, \& Riant. (2004). Kebijakan Publik, Formulasi, Implementasi, dan. Evaluasi. Jakarta: Gramedia.

Prasetyanto. (2012). Dampak alokasi dana desa pada era desentralisasi fiskal terhadap perekonomian daerah di indonesia. Institute Pertanian Bogor.

Prasetyo, Y., \& Masdjojo, G. N. (2013). Imlementasi Kebijakan Alokasi Dana Desa di 10 Desa Wilayah Kecamatan Rembang Kabupaten Rembang. In Prosiding Seminar Nasiona Multi Disiplin Ilmu \& Call For Paper Unisbank (pp. 978-979).

Rusydi, H. M. (2012). Pengaruh Alokasi Dana Desa terhadap Kesejahteraan Masyarakat Desa di Kabupaten Takalar. Jurnal Ekonomi Balance, 8(2), 152-176.

Saputra, I. W. (2016). Efektivitas Pengelolaan Alokasi Dana Desa Pada Desa Lembean Kecamatan Kintamani , Kabupaten Bangli Tahun 2009-2014. Jurnal Jurusan Pendidikan Ekonomi (JJPE), 2009(2). 